\title{
New missions of a hospital pharmaceutical updates technology unit during the COVID-19 pandemic
}

\author{
Alexandra Garnier ${ }^{1,2^{*}}$ (D) Ludivine Falaschi ${ }^{1}$, Pascal Bonnabry ${ }^{1,2}$ and Lucie Bouchoud ${ }^{1}$
}

\begin{abstract}
The pharmaceutical technology unit of the Geneva University Hospitals played a significant role in the fight against COVID-19 through four different missions: (1) providing enough hydroalcoholic solution at the peak of the pandemic; (2) facing supply chain management issues; (3) adapting the workload to the crisis and, above all, (4) managing the human resources necessary to handle these activities.
\end{abstract}

Keywords: COVID-19, Pharmaceutical technology, Hydroalcoholic solution, Human resources

\section{Introduction}

On March 16th 2020, the Federal Council declared Switzerland to be in an "extraordinary situation". The Geneva University Hospitals (HUG) is one of the five university hospitals of Switzerland and the largest one in the country with 2000 beds and 11,000 employees. In the same way as many hospital pharmacists fought the COVID19 pandemic [1], HUG's pharmaceutical technology unit (PTU) took new responsibilities.

\section{Mission 1: providing hydroalcoholic solution}

At the peak of the pandemic, the HUG's consumption of hydroalcoholic solution was multiplied by three. The external supplier was overwhelmed and a shortage in hydroalcoholic solution was threatening. Therefore, the PTU started a production chain on March 6th, 1 month before the most critical time of the pandemic. Within 3 weeks, $1120 \mathrm{~L}$ had been produced as per the OMS formula [2]. In April, Firmenich, a Swiss fragrance and flavor company, decided to use its own chain to produce and send cans of hydroalcoholic solution to the pharmacy, to be conditioned in $100-\mathrm{mL}$ and $500-\mathrm{mL}$ bottles and distributed. On August 11th, 10,000 L of hydroalcoholic

*Correspondence: alexandra.garnier@hcuge.ch

${ }^{1}$ Geneva University Hospitals, Street Gabrielle-Perret-Gentil 4, 1205 Geneva, Switzerland

Full list of author information is available at the end of the article solution had been filled in bottles which were closed, labeled, stored and sent to hospital care units. This unusual situation should go back to normal in November, when the supplier is able to furnish enough hydroalcoholic solution again. Considering that it was impossible to obtain anywhere such quantities of hydroalcoholic solution and that 6 months were necessary for the supplier to adapt his production, these reactivity and anticipation were primordial and proved to be incredibly useful.

Part of this mission was the recycling of used bottles which were washed and filled again. Collection points were efficiently organized and the entire hospital participated in this collective effort.

\section{Mission 2: facing supply chain management issues} In HUG, the demand in reanimation drugs increased by ten times during the pandemic, although the world was facing shortages related to the lack of active pharmaceutical ingredients from China, the first country to be hit by the virus. To face these supply chain management issues, the pharmacy switched to unusual suppliers and received drugs from various non-French-speaking countries. In a very short time, the PTU handled the relabeling of 21,000 ampules of atracurium from Portugal, 20,000 ampules of propofol for Germany, 5000 vials of Esmeron from South Korea and 220 vials of remdesivir initially used for a clinical trial. original author(s) and the source, provide a link to the Creative Commons licence, and indicate if changes were made. The images or other third party material in this article are included in the article's Creative Commons licence, unless indicated otherwise in a credit line to the material. If material is not included in the article's Creative Commons licence and your intended use is not permitted by statutory regulation or exceeds the permitted use, you will need to obtain permission directly from the copyright holder. To view a copy of this licence, visit http://creativecommons.org/licenses/by/4.0/. The Creative Commons Public Domain Dedication waiver (http://creativeco mmons.org/publicdomain/zero/1.0/) applies to the data made available in this article, unless otherwise stated in a credit line to the data. 


\section{Mission 3: adapting usual missions}

Several clinical activities in the hospital were reduced or stopped to take over COVID+ patients, leading to: (1) reevaluating the need of some planned serial productions; (2) suspending clinical trials; (3) postponing some chemotherapy treatments and (4) stopping autologous serum production. A global shortage in sampling tests lead to a collaboration with the virology laboratory to develop a DMEM culture medium used for the PCR screening of COVID-19 cases. Therefore, this saved time was reinvested to fill $30^{\prime} 000$ sterile tubes of this reactant, representing more than $130 \mathrm{~h}$ of work on 31 days.

\section{Mission 4: preserving human resources}

Guaranteeing the continuity of human resources by identifying key functions and vulnerable employees was a challenge. Every holiday until April 30th were canceled on March 13th. Not to exhaust the team, recovery days were maintained at the PTU. Usually, the unit works with a minimum of 7 technicians, 2 assistant-technicians and 2 pharmacists. For a worst-case scenario, the minimum was decided to be 4 technicians, 1 assistant-technician and 1 pharmacist during a few days versus 5 technicians, 2 assistant-technicians and 1 pharmacist if the crisis lasted for several weeks.

Other options were considered: (1) increasing some employees' work rate; (2) collaborating with community pharmacies or the hospital of Vaud canton; (3) having technicians back from other units and (4) calling back some retirees. The first option was applied and one parttime collaborator worked on a $100 \%$ basis during one month. Furthermore, 11 volunteers joined the PTU, furnishing the equivalent of 90 days of work, essentially used for the filling of hydroalcoholic solution.

Pharmacists also started to work remotely with several missions: (1) double control of volumes with pictures; (2) liberation of pharmaceutical preparations; (3) creation and validation of protocols; (4) phone calls to suppliers and (5) invoice of cytotoxic preparations to care units.

\section{Conclusion}

The HUG's PTU has faced many challenges during the COVID-19 pandemic. From historical perspective, it is an unprecedented situation that can be now considered as a great opportunity to apply in the future the keywords adaptation, resilience and rigor.

\section{Authors' contributions}

All authors read and approved the final manuscript.

Funding

There was no financial support.

Availability of data and materials

The datasets used in this paper are available from the corresponding author.

Ethics approval and consent to participate

Not applicable.

\section{Competing interests}

The authors declare no competing interests.

\section{Author details}

${ }^{1}$ Geneva University Hospitals, Street Gabrielle-Perret-Gentil 4, 1205 Geneva, Switzerland. ${ }^{2}$ Institute of Pharmaceutical Sciences of Western Switzerland,

School of Pharmaceutical Sciences, University of Geneva, Street Michel-Servet 1, 1205 Geneva, Switzerland.

Received: 10 November 2020 Accepted: 3 December 2020 Published online: 06 January 2021

\section{References}

1. Bukhari N, Rasheed H, Nayyer B, et al. Pharmacists at the frontline beating the COVID-19 pandemic. J Pharm Policy Pract. 2020;13:8. https://doi. org/10.1186/s40545-020-00210-w.

2. Guide to Local Production: WHO-recommended Handrub Formulations. Revised April 2010. https://www.who.int/gpsc/5may/Guide_to_Local _Production.pdf. Accessed 12 Oct 2020.

\section{Publisher's Note}

Springer Nature remains neutral with regard to jurisdictional claims in published maps and institutional affiliations.
Ready to submit your research? Choose BMC and benefit from:

- fast, convenient online submission

- thorough peer review by experienced researchers in your field

- rapid publication on acceptance

- support for research data, including large and complex data types

- gold Open Access which fosters wider collaboration and increased citations

- maximum visibility for your research: over $100 \mathrm{M}$ website views per year

At BMC, research is always in progress.

Learn more biomedcentral.com/submissions 